\title{
Systemic Meta-analysis of Mastitis Prevalence in Dairy Cattle and Goat of Bangladesh
}

\author{
Mahamudul Hasan ${ }^{1, a, *}$ \\ ${ }^{1}$ Faculty of Veterinary, Animal and Biomedical Sciences (SAU), Sylhet Agricultural University, Sylhet-3100, Bangladesh \\ *Corresponding author \\ A R T I C L E I N F O A B S T R A C T \\ Research Article \\ Bovine and caprine mastitis is a dreadful bacterial disease that drastically lowers milk production, \\ and presently it is spreading as an endemic pathogen throughout the world, including Bangladesh. \\ Moreover, mastitis is the main impediment to Bangladesh's tremendously rising milk-related \\ industry and general livestock economy. Therefore, the aim of this study is to demonstrate the \\ Received : $17 / 12 / 2020$ \\ Accepted : 01/03/2021 \\ overall prevalence of clinical and sub-clinical mastitis in both dairy cows and goats. It is the \\ foremost meta-analysis study regarding mastitis prevalence in Bangladesh and the study gathered \\ the articles from the electronic database on the topic bovine and caprine mastitis published between \\ January 2005 and November 2020. Finally, 33 articles were selected for estimating the overall \\ prevalence rate of mastitis in ruminant (cow and goat) via random effect model estimation. \\ Analyzing the result, the study found $43.0 \%(95 \% \mathrm{Cl}: 37.0-50.0 \%)$ and $31.0 \%(95 \% \mathrm{Cl}: 15.0-$ \\ Keywords: \\ Mastitis \\ Prevalence \\ Bangladesh \\ Meta-analysis \\ Ruminant \\ $47.0 \%$ ) prevalence rate in dairy cattle and goat. Statistically, the occurrence rate in Bangladesh is \\ significantly higher than other countries. Although many studies showed the seroprevalence across \\ different districts, this study demonstrates the aggregate incidence rates across Bangladesh as a \\ whole. This paper may also serve as a reference point for the implementation of any control strategy \\ of mastitis in Bangladesh.
}

\section{Introduction}

Mastitis becomes one of the most infectious complications in milking animal, including cow and goat worldwide. It is perceived to be an economically terrible disease that impedes the milk sector's growing demand (Bangar et al., 2014). Besides, mastitis is a mortifying dairy animal's disease characterized by significantly reduces milk production, declines in the quality and quantity of milk, and production costs (Hogeveen et al., 2011). There are two primary sorts of mastitis (clinical and sub-clinical) characterized by the inflammation of the udder and teats (Ruegg, 2017; Taponen et al., 2017).

Swelling of the udder and persistence of the flakes in milk is a familiar typical indication of clinical mastitis (K.P. Suresh et al., 2017). In contrast, the diagnosis of subclinical mastitis is difficult due to the lack of obvious clinical signs that exist longer effectively in herds and are correlated with higher loss (Abrahmsén et al., 2014; Ndahetuye et al., 2019; Zeryehun and Abera, 2017).
Previously, the prevalence of mastitis was recorded in many studies in Bangladesh and reported a fluctuate rational result. Some studies showed a higher prevalence, and the rest studies indicated a lower prevalence percentage. Perhaps, this variation occurs due to the research duration and region, lactation period, animal breed, sample size, sampling method, and farm management practice (K.P. Suresh et al., 2017). As Bangladesh is a developing country with a huge population and the majority of the people live in the rural area depend on livestock besides agricultural farming. Mainly, Cattle and goats are the main domestic animal in Bangladesh (Hasib and Chowdhury, 2020; S. Rahman, 2018). Meanwhile, mastitis in the bovine and caprine population is becoming an impediment for the dairy sector as well as farmer livelihood. To overcome this disease, the strategic managemental initiative could play an important role in lessening further outbreaks. Therefore, gathering information about the prevalence of the previous study is 
essential for guiding the policymaker. Thus, this study provides a vivid impression of the overall pooled prevalence estimate of mastitis for both dairy cattle and goats via systemic review and meta-analysis method.

\section{Materials and Methods}

\section{Methods}

The research was performed in compliance with the directives supported for review and meta-analysis by PRISMA (Preferred Reporting Items for Systematic Reviews and Meta-Analyses) (Ahaduzzaman, 2019; Hasib and Chowdhury, 2020).

\section{Literature Search}

Conducting a study, the term related to mastitis in Bangladesh was searched in Google Scholar, PubMed, Science Direct, and local Bangladeshi journals. Mastitis, prevalence, and Bangladesh were the core terms used in the process of electronic search. Besides, the terms, including bovine, caprine, clinical, and sub-clinical were also included in the search procedure. Only, the articles of the English language were aggregated for leading this study. Searching the papers was done from the 5th of December to the 7th of December, 2020.

\section{Data Extraction}

The data, including author, study year, study place, study duration, total sample, positive cases, type of mastitis, and the species of animal were extracted in an excel spreadsheet. Finally, data obtained from 7011 dairy cows and 3866 dairy goats were selected for analyzing this study.

\section{Selection of Study}

The studies were selected based on five objectives for including in the meta-analysis, including (1) published in the English language, (2) cross-sectional, (3) included the number of total and affected animals, (4) sampling based on the individual animal, (5) published between January 2005 to November 2020, and, (6) diagnosed by (California mastitis test) CMT or other equivalent test and clinical examination. Those studies were omitted, which proved to fail to fulfill the described objectives.

\section{Statistical Analysis}

Total sample size and frequency of positive case (calculated average positive sample in case of the individual result of more than two tests) for each study were inserted in Microsoft office Excel 2019, and variance of the studies was calculated (Neyeloff et al., 2012). Following this, Jamovi 1.2.27 software was used for further calculation including, a 95\% CI, heterogenicity test, and chi-square test for knowing the significance of the variance among estimates $(\mathrm{P}<0.001)$.

After getting some of the basic requirements, the overall meta-analysis was visualized in the forest plot (random model) along with the funnel plot. In the forest plot, a horizontal line denotes the result of a study. In contrast, the $95 \%$ confidence interval $(\mathrm{Cl})$ and the point estimate of each study are represented by the length of the line and the black box (Getaneh and Gebremedhin, 2017). Moreover, the weight of each study is proportional to the zone of the black box. Both Figure 2 and Figure 4 represent the forest plot, where the study and author name present in the left-side column. Similarly, the first column of the right-side remarks weight, the second one represents proportion combined with the range of $95 \% \mathrm{Cl}$.

\section{Results}

\section{Search Results (eligible studies)}

Searching at the initial stage, 88 articles were found from PubMed, Science Direct, Google scholar. After accessing the irrelevant and duplicate articles, the number of the articles were 60 . Then, screening, reading abstract, and accessing the objectives mentioned above, only 33 articles (26 on dairy cows and 7 on dairy goats) were chosen visualized in Figure 1. The eligible studies are presented under the study column of Table 1 and Table 2.

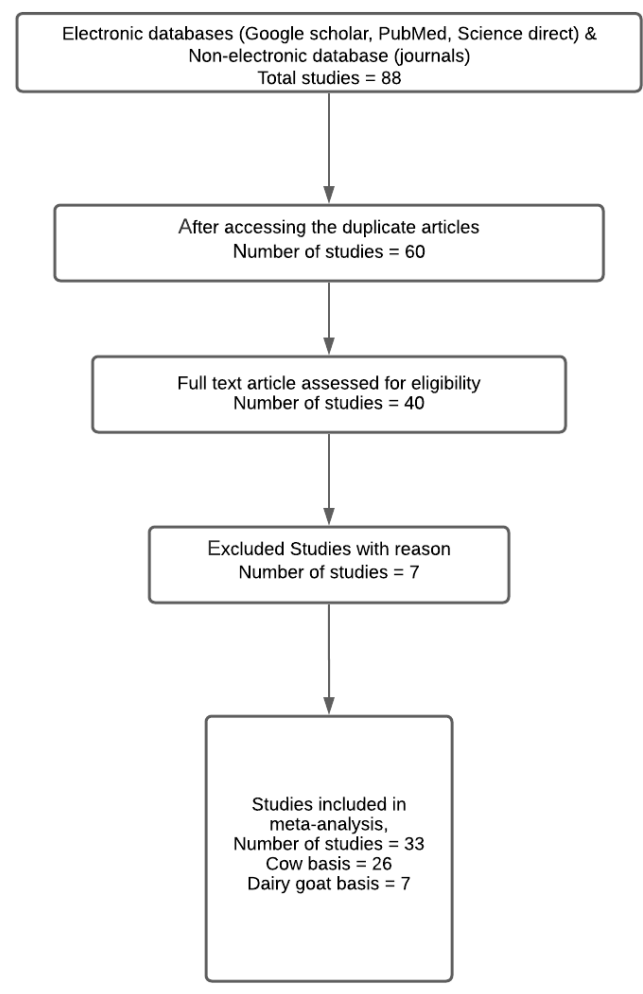

Figure 1. Flow diagram of the method of studies selection for the meta-analysis

\section{Prevalence Estimation}

Table 1, Table 2, and Table 3 represents the total metaanalysis result of mastitis, including clinical and subclinical-mastitis in selected species (dairy cow and lactating goat). Obtaining data from a total of 10877 animals including, 7011 dairy cows and 3866 dairy goats were used for meta-analysis. In the result section, the random effect model showed the overall prevalence of both types of mastitis was $43.0 \%$, where the $95 \%$ CI was 37.0 $50.0 \%$ in the dairy cow. Similarly, the overall prevalence of mastitis was $31.0 \%$ (95\% CI: $15.0-47.0 \%$ in dairy goat. Moreover, significant heterogeneity $(\mathrm{Q}=1688.425$ for cow and $\mathrm{Q}=254.932$ for dairy goat) was perceived between the studies, where inverse variance index value $\left(\mathrm{I}^{2}\right)$ was $97.8 \%$ for cow and $99.6 \%$ for dairy goat presented in Table 3 . 
Table 1. Description of each selected study for calculating meta-analysis in dairy cattle.

\begin{tabular}{|c|c|c|c|c|c|}
\hline Study & $\begin{array}{c}\text { Location } \\
\text { (District in Bangladesh) }\end{array}$ & $\begin{array}{c}\text { Duration } \\
\text { (Year) }\end{array}$ & $\begin{array}{c}\text { Total } \\
\text { Sample }\end{array}$ & $\begin{array}{c}\text { Positive case } \\
(\%)\end{array}$ & TM \\
\hline (Kahirl et al., 2008) & Sylhet & 2006 & 456 & $246(53.95)$ & SCM \\
\hline $\begin{array}{l}\text { (M. M. Rahman et al., } \\
\text { 2010) }\end{array}$ & Sylhet & 2008-2009 & 158 & $81(51.27)$ & $\mathrm{SCM}$ \\
\hline (Uddin et al., 2010) & Chittagong & 2008 & 306 & $215(70.26)$ & SCM \\
\hline (M. A. Islam et al., 2010) & Sirajganj & 2009 & 330 & $120(36.36)$ & SCM \\
\hline (Rabbani and Samad, 2010) & Mymensingh & 2008 & 116 & $51(43.97)$ & SCM \\
\hline (M. M. Islam et al., 2012) & Chittagong & 2011 & 602 & $124(20.60)$ & $\mathrm{CM}$ \\
\hline (M. Islam et al., 2012) & Mymensingh \& Tangail & $2009-2010$ & 200 & $58(29.00)$ & SCM \\
\hline (Haque et al., 2014) & Satkhira & $2012-2013$ & 150 & $52(34.67)$ & $\mathrm{CM} \& \mathrm{SCM}$ \\
\hline (Kayesh et al., 2014) & Barishal & 2013-2014 & 200 & $57(28.50)$ & SCM \\
\hline (Siddiquee et al., 2014) & Mymensingh & 2011-2012 & 158 & $87(55.06)$ & SCM \\
\hline (Quaderi et al., 2014) & Mymensingh \& Dhaka & $2005-2007$ & 560 & $380(67.86)$ & SCM \\
\hline (Tripura et al., 2014) & Mymensingh \& Lakshmipur & 2011-2012 & 139 & $72(51.80)$ & SCM \\
\hline (Barua et al., 2014) & Chittagong & 2012 & 444 & $144(32.43)$ & SCM \\
\hline (Hoque et al., 2014) & $\begin{array}{l}\text { Chittagong, Dhaka, Sirajganj, } \\
\text { Mymensingh \& Gazipur }\end{array}$ & 2014 & 228 & $148(64.91)$ & SCM \\
\hline (Saha. et al., 2014) & Chittagong & $2013-2014$ & 153 & $100(65.36)$ & SCM \\
\hline (Bari et al., 2016) & Chittagong & 2013 & 634 & $53(8.36)$ & $\mathrm{CM}$ \\
\hline (Hossain et al., 2016) & Jesssor & 2013 & 432 & $65(15.05)$ & $\mathrm{CM}$ \\
\hline (Khokon et al., 2017) & Chittagong & $2011-2013$ & 100 & $69(69.00)$ & CM \& SCM \\
\hline (Biswas and Sarker, 2017) & Barishal & 2014 & 64 & $33(51.56)$ & SCM \\
\hline (Kabir et al., 2017) & Sirajganj & $2015-2016$ & 300 & $153(51.00)$ & SCM \\
\hline (Nahian et al., 2018) & Satkhira & 2018 & 250 & $66(26.40)$ & SCM \\
\hline (Meher et al., 2018) & Barishal & 2016-2017 & 152 & $54(35.53)$ & SCM \\
\hline (Arman et al., 2018) & Dhaka \& Chittagong & 2017 & 287 & $118(41.11)$ & SCM \\
\hline (S. Islam et al., 2019) & Chittagong & 2015 & 114 & $39(34.21)$ & SCM \\
\hline (Bhuiyan et al., 2020) & Brahmanbaria & 2018 & 400 & $115(28.75)$ & $\mathrm{SCM}$ \\
\hline (Sayeed et al., 2020) & Jhenaidah & 2019 & 78 & $53(67.95)$ & SCM \\
\hline
\end{tabular}

TM: Type of Mastitis, SCM: Sub-clinical Mastitis, CM: Clinical Mastitis

Table 2. Description of each selected study for calculating meta-analysis in dairy goat.

\begin{tabular}{l|lcccc}
\hline \multicolumn{1}{c|}{ Study } & \multicolumn{1}{c}{ Location (District in Bangladesh) } & $\begin{array}{r}\text { Duration } \\
(\text { Year) }\end{array}$ & $\begin{array}{c}\text { Total } \\
\text { Sample }\end{array}$ & $\begin{array}{c}\text { Positive case } \\
(\%)\end{array}$ & TM \\
\hline (Amin et al., 2011) & Mymensingh & 2009 & 2042 & $90(4.41)$ & SCM \\
(A. Islam et al., 2012) & N/A & 2009 & 231 & $90(38.96)$ & SCM \\
(Sarker and Samad, 2013) & Mymensingh \& Joypurhat & 2010 & 1025 & $54(5.27)$ & CM \\
(Razi et al., 2013) & Mymensingh & $2010-2011$ & 50 & $11(22.00)$ & SCM \\
(Begum et al., 2016) & Rajshahi and Rangpur & $2008-2010$ & 292 & $164(56.16)$ & SCM \\
(Ferdous et al., 2018) & Dinajpur & 2017 & 120 & $52(43.33)$ & SCM \\
(Akter et al., 2020) & Chittagong & 2019 & 106 & $54(50.94)$ & SCM \\
\hline
\end{tabular}

TM: Type of Mastitis, SCM: Sub-clinical Mastitis, CM: Clinical Mastitis

Table 3. Overall prevalence rate with heterogeneity of mastitis in dairy cattle and goat.

\begin{tabular}{l|llllllr}
\hline Species & Total Sample & Pooled estimate (\%) & $95 \%$ CI & Heterogeneity $(\chi 2)$ & $\mathrm{I}^{2}(\%)$ & P-value & Tau \\
\hline Cow & 7011 & 43.0 & $37-50$ & 1688.425 & 97.8 & $<.001$ & 0.031 \\
Goat & 3866 & 31.0 & $15-47$ & 254.932 & 99.6 & $<.001$ & 0.044 \\
\hline
\end{tabular}

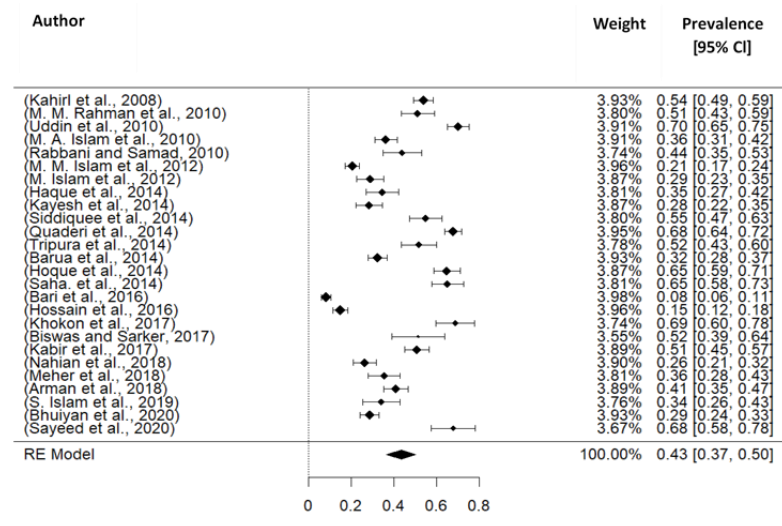

Figure 2. Forest plot showing the estimate prevalence rate of mastitis in dairy cattle of Bangladesh

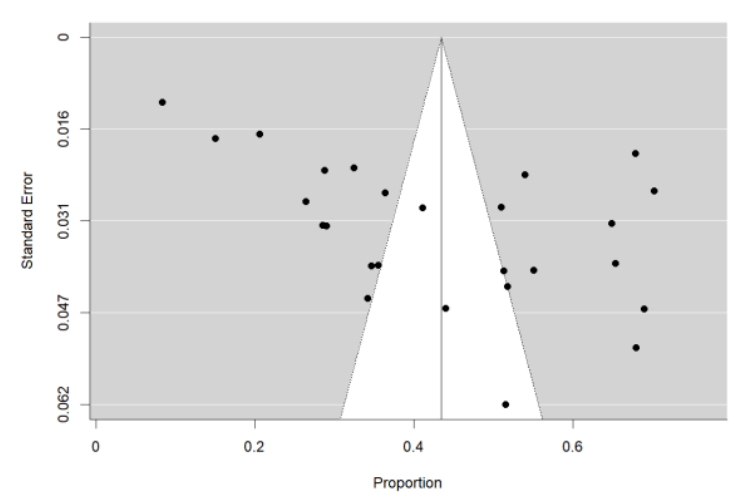

Figure 3. The disseminating points of the funnel plot show the overall estimate prevalence, along with publication bias in the dairy cattle of Bangladesh 
The overall prevalence, along with separate occurrence was presented in Figure 2 and Figure 4. Besides, funnel plot individually for the cow, and dairy goat represents publication bias by presenting the non-symmetrical shape of a funnel with dropping the points exterior to the funnel (Figure 3 and Figure 5).

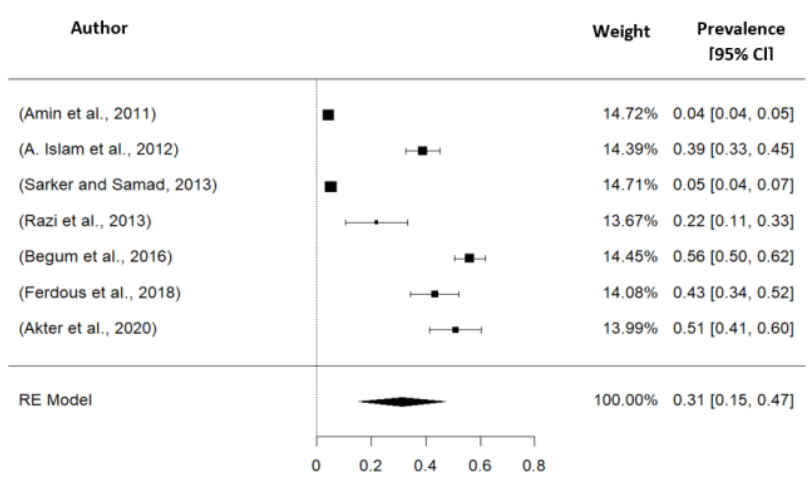

Figure 4. Forest plot showing the estimate prevalence rate of mastitis in dairy goat of Bangladesh

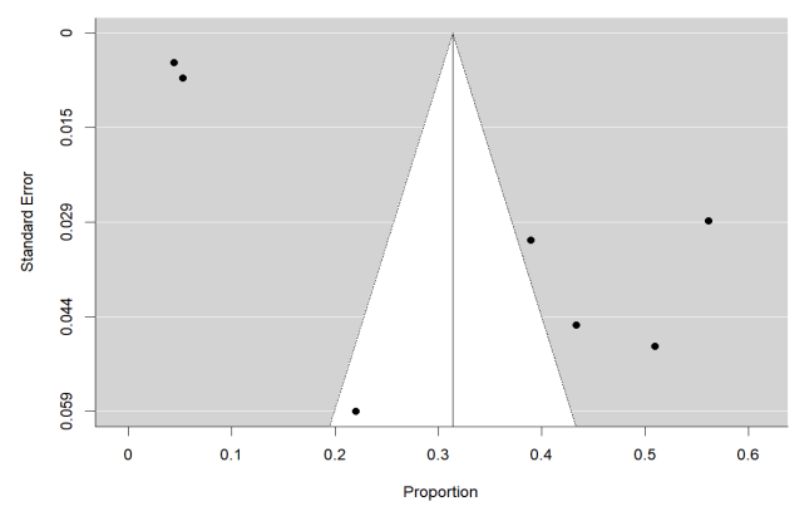

Figure 5. The disseminating points of the funnel plot show the overall estimate prevalence, along with publication bias in the dairy goat of Bangladesh

\section{Discussion}

Mastitis is one of the most common bacterial diseases in cattle, while it is also seen in Bangladesh's dairy goat population. Thus, the prevalence rate of mastitis has been shown in previous researches, but this is the first study to analyse the outline of the overall random model pooled prevalence rate in cattle and dairy goats using the metaanalysis process. Analysing the result, the significant inverse variation indexes of overall prevalence rate in cow and dairy goat between the respective studies imply a strong heterogenicity index. The findings showed that Chittagong and Mymensingh had the highest number of study locations due to the existence of reputable agricultural institutes in those regions. Variations in cow level factors, agroclimatic circumstances, and farm management tradition could be linked to distinct outcome (Getaneh and Gebremedhin, 2017; Joshi and Gokhale, 2006).

The meta-analysis summarized that the estimated prevalence rate was $43.0 \%$ (95\% CI: $37.0-50.0 \%$ ) in dairy cow, which is lower than another study reported in Ethiopia found $47.0 \%(95 \% \mathrm{CI}=42.0-52.0 \%)$ prevalence rate (Getaneh and Gebremedhin, 2017). Similarly, in regions of Kenya, the overall prevalence rate of mastitis was calculated to $80 \%$, which is far higher than the present meta-analysis summarizes (Mbindyo et al., 2020). In contrast, rendering to a recent study, the overall occurrence rate of mastitis among cows in one segment of India was $5.1 \%$ indicates significantly lower occurrence than the current study findings (Dutta and Gowder, 2018). On the other hand, few research on the prevalence of mastitis in dairy goats were obtained due to their decreased susceptibility; among them, one study showed a $40.4 \%$ prevalence rate in Nigeria, which was lower than the present study's outcome (31.0\%) (Danmallam and Pimenov, 2019). Dissimilarly, another research held in Kenya listed $72.7 \%$ prevalence rate of mastitis among dairy goats (Okoko et al., 2020). Finally, in Ethiopia, Alemu and Abraha, 2017 found that the prevalence rate of mastitis in cows and goats was $48.0 \%$ and $30.8 \%$, respectively, concluding the cattle population has a greater susceptible rate than the goat population.

To sum up, this study demonstrated the combined prevalence of clinical and subclinical mastitis in Bangladeshi dairy animals (cow and goat) using a random model effect. Thus, the general conclusion of the prevalence rate is notably conspicuous in the cattle population. Moreover, this prevalence rate has the potential to have a significant impact on Bangladesh's rapidly expanding milk production and processing infrastructure. This study also recommends that farmers should enrich the knowledge about the essential management system.

\section{Limitations}

This research presents only pooled extermination without taking into account the troubling causes, including risk factors, climatic conditions, and disease connotations. In addition, all the paper chosen was not taken homogeneously from around the country.

\section{Acknowledgements:}

The author is thankful to Dr. Mukthar Mia, Department of Poultry Science, SAU for providing guideline.

\section{References}

Abrahmsén M, Persson Y, Kanyima BM, Båge R. 2014. Prevalence of subclinical mastitis in dairy farms in urban and peri-urban areas of Kampala, Uganda. Tropical Animal Health and Production, 46: 99-105. https://doi.org/ 10.1007/s11250-013-0455-7

Ahaduzzaman M. 2019. The global and regional prevalence of oestrosis in sheep and goats: A systematic review of articles and meta-analysis. Parasites and Vectors, 12: 346. https://doi.org/10.1186/s13071-019-3597-2

Akter S, Rahman MM, Sayeed MA, Islam MN, Hossain D, Hoque MA, Koop G. 2020. Prevalence, aetiology and risk factors of subclinical mastitis in goats in Bangladesh. Small Ruminant Research, 184: 1-6. https://doi.org/10.1016/ j.smallrumres.2020.106046

Alemu S, Abraha A. 2017. Prevalence of bacteria associated with subclinical mastitis in haramaya university dairy cattle, goat and sheep farms. East African Journal of Veterinary and Animal Sciences, 1: 61-66. 
Amin M, Samad M, AKM A. 2011. Bacterial pathogens and risk factors associated with mastitis in black Bengal goats in Bangladesh. Bangladesh Journal of Veterinary Medicine, 9: 155-159.

Arman S, Amin M Al, Rahman M, Bhattacharjee J, Bhuiyan M. 2018. Prevalence and its influencing risk factors of subclinical mastitis in crossbred Friesian cows. Bangladesh Veterinarian, 34: 42-51. https://doi.org/10.3329/ bvet.v34i2.49887

Bangar YC, Singh B, Dohare AK, Verma MR. 2014. A systematic review and meta-analysis of prevalence of subclinical mastitis in dairy cows in India. Tropical Animal Health and Production, 47: 291-297. https://doi.org/ 10.1007/s11250-014-0718-y

Bari M, Alam M, Uddin M, Rahman M. 2016. Prevalence and associated risk factors of bovine clinical mastitis in Patiya upazila under Chittagong district of Bangladesh. International Journal of Natural Sciences, 4: 5-9. https://doi.org/10.3329 /ijns.v4i1.28585

Barua M, Prodhan MAM, Islam K, Chowdhury S, Hasanuzzaman M, Imtiaz MA, Das GB. 2014. Sub-clinical mastitis prevalent in dairy cows in Chittagong district of Bangladesh: Detection by different screening tests. Veterinary World, 7: 483-488. https://doi.org/10.14202/vetworld.2014.483-488

Begum M, Hossain M, Ershaduzzaman M, Alam M. 2016. Epidemiological studies on subclinical mastitis in dairy goats in northern regions of Bangladesh. Bangladesh Journal of Livestock Research, 19: 112-122. https://doi.org/10.3329/ bjlr.v19i1-2.26433

Bhuiyan MU, Shahadat HM, Chakma SS, Islam F, Islam R, Islam T, Mahfuz S. 2020. Prevalence of subclinical mastitis of dairy cows in bijoynagar upazila under brahmanbaria district of Bangladesh. Advances in Animal and Veterinary Sciences, 8: 364-369. https://doi.org/10.17582/JOURNAL.AAVS/2020/8.4.364.369

Biswas D, Sarker T. 2017. Prevalence of sub-clinical mastitis at banaripara upazilla, barisal. Bangladesh Journal of Veterinary Medicine, 15: 21-26. https://doi.org/10.3329/bjvm.v15i1.34050

Danmallam FA, Pimenov NV. 2019. Study on prevalence, clinical presentation, and associated bacterial pathogens of goat mastitis in bauchi, plateau, and edo states, nigeria. Veterinary World, 12: 638-645. https://doi.org/10.14202/ vetworld.2019.638-645

Dutta R, Gowder RO. 2018. The prevalence and predisposing factors of mastitis in lactating mothers in puerperium. The New Indian Journal of OBGYN, 5: 28-32. https://doi.org/ 10.21276/obgyn.2018.5.1.7

Ferdous J, Rahman M, Khan M, Khan M, Rima U. 2018. Prevalence of clinical and subclinical caprine mastitis of northern region in Bangladesh. Progressive Agriculture, 29: 127-138. https://doi.org/10.3329/pa.v29i2.38296

Getaneh AM, Gebremedhin EZ. 2017. Meta-analysis of the prevalence of mastitis and associated risk factors in dairy cattle in Ethiopia. Tropical Animal Health and Production, 49: 697-705. https://doi.org/10.1007/s11250-017-1246-3

Haque ME, Islam MA, Akter S, Saha S. 2014. Identification, molecular detection and antibiogram Profile of bacteria isolated from california mastitis test positive milk samples of crossbred cows of satkhira district in Bangladesh. GSTF Journal of Veterinary Science, 1: 59-63. https://doi.org/ 10.5176/2345-7880_1.1.8

Hasib FMY, Chowdhury S. 2021. Review and meta-analysis of PPR in goat and sheep of Bangladesh from 2000 to 2019. Turkish Journal of Agriculture - Food Science and Technology, 8: 2099-2104. https://doi.org/10.24925/ turjaf.v8i10.2099-2104.3557

Hogeveen H, Huijps K, Lam TJGM. 2011. Economic aspects of mastitis: New developments. New Zealand Veterinary Journal, 59: 16-23. https://doi.org/10.1080/00480169. 2011.547165
Hoque MN, Das ZC, Talukder AK, Alam MS, Rahman ANMA. 2014. Different screening tests and milk somatic cell count for the prevalence of subclinical bovine mastitis in Bangladesh. Tropical Animal Health and Production, 47: 7986. https://doi.org/10.1007/s11250-014-0688-0

Hossain S, Reza MA, Hasan MN, Sorwar MG, Billah M. 2016. Impact of clinical mastitis in dairy farming at Keshabpur Upazilla in Jessore in Bangladesh. Bangladesh Journal of Veterinary Medicine, 14: 59-64. https://doi.org/10.3329/ bjvm.v14i1.28825

Islam S, Barua SR, Islam A, Moni SP, Uddin H, Ferdous J, Rahman MK, Hassan MM, Rahman AKMA, Chawdhury S. 2019. Epidemiology of Sub-Clinical Mastitis in Dairy Cows in Urban Areas of Chittagong, Bangladesh. Turkish Journal of Agriculture - Food Science and Technology, 6: 845-850. https://doi.org/10.24925/turjaf.v7i6.845-850.2288

Islam M, Islam M, Islam M, Rahman M, Islam M. 2012. Prevalence of subclinical mastitis in dairy Cows in selected areas of Bangladesh. Bangladesh Journal of Veterinary Medicine, 9: 73-78. https://doi.org/10.3329/bjvm.v9i1.11216

Islam MM, Rahman MM, Bhuiyan MMU, Shamsuddin M. 2012. Prevalence and rational treatment of clinical mastitis in crossbred dairy cows. Bangladesh Veterinary Journal, 46: 1-10.

Islam MA, Rony SA, Islam MS, Science V. 2010. Prevalence and risk factors of mastitis in lactating dairy cows at Baghabari milk shed area of Sirajganj. Bangladesh Journal of Veterinary Medicine, 8: 157-162.

Islam A, Samad A, Rahman AKMA. 2012. Prevalence of subclinical caprine mastitis in Bangladesh based on parallel interpretation of three screening tests. International Journal of Animal and Veterinary Advances, 4: 225-228.

Joshi S, Gokhale S. 2006. Status of mastitis as an emerging disease in improved and periurban dairy farms in India. Annals of the New York Academy of Sciences, 8: 74-83. https://doi.org/10.1196/annals.1373.007

Suresh PK, G. Govindaraj SS, Parimal Roy BRS. 2017. Metaanalysis of prevalence of subclinical and clinical mastitis, major mastitis pathogens in dairy cattle in India. International Journal of Current Microbiology and Applied Sciences, 6: 1214-1234. https://doi.org/10.20546/ ijcmas.2017.603.141

Kabir MH, Ershaduzzaman M, Giasuddin M, Islam MR, Nazir KHMNH, Islam MS, Karim MR, Rahman MH, Ali MY. 2017. Prevalence and identification of subclinical mastitis in cows at BLRI Regional Station, Sirajganj, Bangladesh. Journal of Advanced Veterinary and Animal Research, 4: 295-300. https://doi.org/10.5455/javar.2017.d227

Kahirl A, Islamz M, Rahman AKMA, Rahman S, Songa H. 2008. prevalence and risk factors of subclinical bovine mastitis in some dairy farms of Sylhet district of Bangladesh. Korean Journal of Veterinary Services, 31: 497-504.

Kayesh M, Talukder M, Anower A. 2014. Prevalence of subclinical mastitis and its association with bacteria and risk factors in lactating cows of Barisal district in Bangladesh. International Journal of Biological Research, 2: 35-38. https://doi.org/10.14419/ijbr.v2i2.2835

Khokon MSI, Azizunnesa, Islam MM, Chowdhury KB, Rahman ML, Ali MZ. 2017. Effect of mastitis on post-partum conception of cross bred dairy cows in Chittagong district of Bangladesh. Journal of Advanced Veterinary and Animal Research, 4: 155-160. https://doi.org/10.5455/ javar.2017.d203

Mbindyo CM, Gitao GC, Mulei CM. 2020. Prevalence, etiology, and risk factors of mastitis in dairy cattle in embu and ajiado Counties, Kenya. Veterinary Medicine International, 2020: 1-12. https://doi.org/10.1155/2020/8831172

Meher MM, Hasan A, Afrin M. 2018. Field Investigation on Subclinical Mastitis in Cows in Different areas of Barisal district in Bangladesh. Turkish Journal of Agriculture - Food Science and Technology, 6: 1159-1162. https://doi.org/10.24925 /turjaf.v6i9.1159-1162.1957 
Nahian JMN, Shohag M, Pal DR, Mollah ML. 2018. Prevalence of subclinal mastitis and its microorganisms in lactating cows at satkhira district of Bangladesh. Wayamba Journal of Animal Science, 1706-1715.

Ndahetuye JB, Persson Y, Nyman AK, Tukei M, Ongol MP, Båge R. 2019. Aetiology and prevalence of subclinical mastitis in dairy herds in peri-urban areas of Kigali in Rwanda. Tropical Animal Health and Production, 51: 2037-2044. https://doi.org/10.1007/s11250-019-01905-2

Neyeloff JL, Fuchs SC, Moreira LB. 2012. Meta-analyses and forest plots using a microsoft excel spreadsheet: Step-by-step guide focusing on descriptive data analysis. BMC Research Notes, 5: 1-6. https://doi.org/10.1186/1756-0500-5-52

Okoko IM, Maina N, Kiboi D, Kagira J. 2020. $\beta$-lactam resistance in bacteria associated with subclinical mastitis in goats in thika subcounty, Kenya. Veterinary World, 13: 1448-1456. https://doi.org/10.14202/vetworld.2020.1448-1456

Quaderi M AL, Husain M, Alam M, Khatun M, Hossain M. 2014. Prevalence of sub-clinical mastitis in dairy farms. Bangladesh Veterinarian, 30: 70-77. https://doi.org/10.3329/ bvet.v30i2.18257

Rabbani AFMG, Samad MA. 2010. Host determinants based comparative prevalence of subclinical mastitis in lactating Holstein-Friesian cross cows and Red Chittagong cows in Bangladesh. Bangladesh Journal of Veterinary Medicine, 8: $17-21$.

Rahman S. 2018. Agroecological, land-elevation and socioeconomic determinants of raising livestock in Bangladesh. Agriculture (Switzerland), 8: 12 https://doi.org/10.3390/agriculture8010012

Rahman MM, Islam MR, Uddin MB, Aktaruzzaman M. 2010. Prevalence of subclinical mastitis in dairy cows reared in Sylhet district of Bangladesh. International Journal of Bio Research, 1: 23-28.

Razi KMA, Rahman MB, Flores-Gutiérrez GH, Rahman MT. 2013. Prevalence of caprine subclinical mastitis in mymensingh Area, Bangladesh and characterization of associated bacterial agents and the risk factors. Microbes and Health, 1: 1-5. https://doi.org/10.3329/mh.v1i1.13705
Ruegg PL. 2017. A 100-Year Review: Mastitis detection, management, and prevention. Journal of Dairy Science, 100: 10381-10397. https://doi.org/10.3168/jds.2017-13023

Saha S, Rahman MM, Munsi MN, Ekram MF, Kabir MH, Rahman MT. 2014. Prevalence of subclinical mastitis in cows at Anwara, a coastal upazila of Chittagong district in Bangladesh. Journal of Veterinary Advances, 6: 594-598.

Sarker H, Samad M. 2013. Udder-halve-wise comparative prevalence of clinical and sub-clinical mastitis in lactating goats with their bacterial pathogens and antibiotic sensitivity patterns in Bangladesh. Bangladesh Journal of Veterinary Medicine, 9: 137-143. https://doi.org/10.3329/bjvm.v9i2.13456

Sayeed MA, Rahman MA, Bari MS, Islam A, Rahman MM, Hoque MA. 2020. Prevalence of subclinical mastitis and associated risk factors at cow level in dairy farms in jhenaidah, Bangladesh. Advances in Animal and Veterinary Sciences, 8: 112-121. https://doi.org/10.17582/journal.aavs/ 2020/8.s2.112.121

Siddiquee N, Tripura T, Islam M, Bhuiyan S, Rahman A, Bhuiyan A. 2014. Prevalence of sub-clinical mastitis in high yielding crossbred cows using Draminski mastitis detector. Bangladesh Journal of Veterinary Medicine, 11: 37-41. https://doi.org/10.3329/bjvm.v11i1.17731

Taponen S, Liski E, Heikkilä AM, Pyörälä S. 2017. Factors associated with intramammary infection in dairy cows caused by coagulase-negative staphylococci, Staphylococcus aureus, Streptococcus uberis, Streptococcus dysgalactiae, Corynebacterium bovis, or Escherichia coli. Journal of Dairy Science, 100: 493-503. https://doi.org/10.3168/jds.201611465

Tripura T, Sarker S, Roy S, Parvin M, Sarker R, Rahman A, Islam M. 2014. Prevalence of subclinical mastitis in lactating cows and efficacy of intramammary infusion therapy. Bangladesh Journal of Veterinary Medicine, 12: 55-61. https://doi.org/ 10.3329/bjvm.v12i1.20464

Uddin M, Hossain MB, Miah G. 2010. Effect of genetic and nongenetic factors on prevalence of sub-clinical mastitis in dairy cows at some selected farms in chittagong district. Journal of Science and Technology, 8: 120-127.

Zeryehun T, Abera G. 2017. Prevalence and bacterial isolates of mastitis in dairy farms in selected districts of eastern harrarghe zone, eastern Ethiopia. Journal of Veterinary Medicine, 2017: 1-6. https://doi.org/10.1155/2017/6498618 